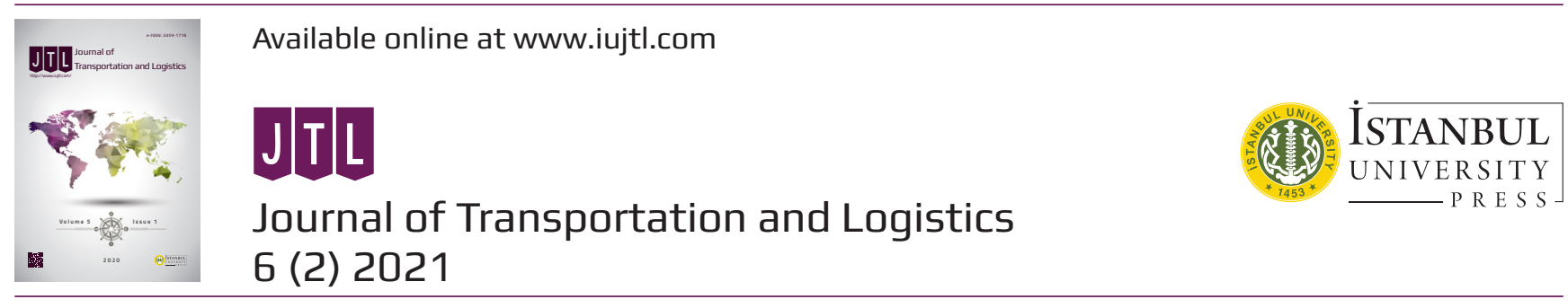

\title{
Determining Passenger Profile According to Types of Transport in Konya: A Clustering Analysis
}

\author{
Nilüfer Canöz ${ }^{1}$, Zeynep Ergen Ișıklar² (i), Ahmet Ertek³ ${ }^{3}$
}

\begin{abstract}
Since the existence of humanity and especially the invention of the wheel, ensuring the movement of persons, objects, living and non-living beings between two points in an economical, ergonomic, fast and safe manner has been the subject of both theoretical and applied research. Today, relevant ministries and local administrations are working on the continuous improvement of transportation infrastructure and facilities. Alternative transportation possibilities about the transportation of people which are developed by taking into account the geographical characteristics, increase the competition in this area day by day. Transportation companies develop strategies directly for the customer in order to be successful in the competitive environment.

In this study, the travel preferences and demographic structure of travellers were associated with a cluster analysis through the types of transportation that exist in the province of Konya. The survey study was analyzed with the SPSS program cluster analysis. As a result it was concluded that when the participants were grouped according to some demographic variables, it was seen that the most dominant modes of transportation were road and air. On the other hand because of Konya's conditions like education / health and business (industry), road, air and railway transportations are preferred.

Keywords: Transportation Preferences, Road Transport, Airline Transportation, Clustering Analysis
\end{abstract}

Submitted/Başvuru: 01.07.2021 • Revision Requested/Revizyon Talebi: 26.07.2021 • Last Revision Received/Son Revizyon: $18.08 .2021 \bullet$ Accepted/Kabul: 23.08 .2021

1 Nilüfer Canöz (Assoc. Prof.), Selcuk University, School of Civil Aviataion, Department of Aviation Management, Konya, Turkey. ncanoz@selcuk.edu.tr ORCID: 0000-0003-3424-3919

2 Corresponding author/Sorumlu yazar: Zeynep Ergen Işıklar (Assist. Prof. Dr.), Selcuk University, School of Civil Aviataion, Department of Aviation Management, Konya, Turkey. zeynepergen@selcuk.edu.tr ORCID: 0000-0001-6223-2227

3 Ahmet Ertek (Res.Assit.), Selcuk University, School of Civil Aviataion, Department of Aviation Management, Konya, Turkey. ahmet.ertek@selcuk.edu.tr ORCID: 0000-0002-8156-5075

Citation/Atnf: Canoz, N., Ergen Isiklar, Z., \& Ertek, A. (2021). Determining passenger profile according to types of transport in Konya: A Clustering Analysis. Journal of Transportation and Logistics, 6(2), 163-176. https://doi.org/10.26650/JTL.2021.960728 


\section{Introduction}

Since the day humanity existed, the transportation sector has existed due to needs such as health, safety and education. Today, the transportation sector enables different cities and countries to contact and connect with each other. The transportation sector is directly related to many sectors such as tourism, logistics, food and industry. Fast, safe, easy and more economical transportation of foodstuffs, raw materials and industrial products is carried out through transportation activities. In this context, it contributes to the development of economic and social opportunities for countries. Thanks to the means of transportation, the quality of life of societies increases and the welfare level of countries rises. In this respect, it can be considered as a development indicator for countries.

Transportation can be defined as transporting people, cargo and mail from one point to another using a transportation vehicle. These activities are carried out in different ways. The reason for this diversity stems from the types of the vehicles used. Accordingly, it is possible to list the types of transport as road transport, air transport, sea transport, railway transport, and pipeline transport (Doğan and Dikmen, 2018: 759). Considering the types of transportation in which different vehicles are used, it is seen that each has advantages and disadvantages compared to the other. Passenger profiles are also as important for the sector as these differences are. Based on this importance, a cluster analysis has been made in this study in order to determine passenger profiles according to the types of transportation operating in Konya. The study has been built within the framework of the road, rail and air transportation types that exist in accordance with the geographical conditions of Konya.

\section{Transportation Activities}

In our study, which aims to determine a passenger profile according to transportation types in order to prevent conceptual confusion, it will be useful to provide information about transportation and transportation activities while stating that the concept of transportation has a correspondence as transmission and shipping concepts in the literature. In this direction, the concept of transportation can be expressed as changing the current position of people and cargo safely in a short time and in a cost-effective manner. The transportation sector is very important in the economic development of Turkey, as it provides continuous transportation of cargo and job opportunities for many people in trades (Sector Analysis Project for Tradesmen and Craftsmen Transport Sector, 2017: 10).

In order to provide a suitable transportation opportunity, coordination between transportation activities should be provided by considering infrastructure, technology, resources and other interactions (Akgüngör and Demirel, 2004: 423-430). Different types of transportation attract attention in ensuring this coordination. The transportation sector consists of various transportation types such as road transport, rail transport, maritime transport, pipelines and air transport, which have different applications within themselves. (Deniz, 2016: 137). 


\subsection{Road Transport}

As Turkey is a connection point between the East and the West due to its geographical location and has a convenient transportation structure, it has always attracted attention to road transport. With the easy and fast realization of favorable conditions and the establishment of the automotive industry in Turkey, road transport has developed very rapidly (MEB Karayolu Taşımacılı̆̆ı, 2011: 5).

Transportation types contain quite different applications within themselves and their preferability varies accordingly. In this direction, road transportation is in the first place for passenger and freight transportation services for Turkey (Deniz, 2016: 138). Road transport is a technology-based service activity based on national and international rules. Road transport can be defined as the process of moving people or loads from one point to another, depending on a certain fee and contract. Transport companies are in constant interaction with customers and legal regulations. Departures and alternative roads, stations, customs, transition areas, vehicles, businesses in operation, rules and regulations are among the factors that affect the demand and supply of road transport (MEB Karayolu Taşımacılı̆̆ı , 2011: 3).

\subsection{Rail Transport}

In the Ottoman period, railway transportation started with a distance of 211 kilometers of track in 1851. However, considering our existing borders apart from the Ottoman period, rail transport activities began with a line of 130 kilometers of track in 1856. By the end of 2020, railway transportation activities had been carried out with a total of 12,803 kilometers (TCDD Annual Report, 2020: 4).

Rail transport is a transportation activity where kilograms of heavy and large loads can be carried out at lower prices. Depending on the vehicles used in this type of transportation, the service provided in terms of quality and time, processes in the same direction. Considering the environment, less damage to the environment and more profitability on long-distance routes are among the advantages of rail transportation. In addition, due to its suitability for public transportation, it helps to eliminate the intensity experienced in other transportation activities (MEB Railway Transport, 2011: 3). Rail transport is more preferable than other transportation types of public transportation, considering its environmental friendliness, reliability and the amount of energy consumed. Therefore, the importance of rail transport has been increasing gradually (Çekerol and Nalçakan, 2011: 321-329).

\subsection{Maritime Transport}

The maritime transport sector, which has developed in line with the technological developments in the world, is used in freight and passenger transportation, industrial trade, live and non-living animal transportation and tourism (Maritime Transportation, 2007: 2). Maritime transport is the preferred type of transportation especially for the transportation of large loads. It is preferred by passengers at a very low rate compared to freight transportation. It is a less costly form of transportation in cases where time is not 
important in the transportation of reliable and large loads such as railway transportation (Deniz, 2016: 145). Environmental friendliness, lower energy consumption, a lack of border crossings in freight transport, and a minimal damage and loss of products are among the factors that affect the preference of maritime transport. Air transport is fourteen times more expensive than maritime transport, seven times more than road transport, and three and a half times more expensive than rail transport. For all these reasons, it is the most preferred type of transportation worldwide. (GISBİR, 2013: 4)

\subsection{Air Transport}

With the effect of constantly developing technology and changing passenger needs, the investments made in the aviation sector are also increasing; parallel to this, air transport is also developing rapidly. Air transport service can be expressed as the displacement of people, cargo and mail by providing a time advantage with their travel in the air using an aircraft (Gerede, 2002: 9). It is a very important sector for Turkey due to its effective use in the fields of tourism and trade. Air transport has started to be used more with the increase in the number of private airline companies and the increase in the number of flights with the effect of liberalization. Another important factor that can be considered in the increase of air transport usage is the increase in the number of airports in Turkey (Bahar, 2018: 26).

Continuous progress is being made in aircraft models, designs and equipment, as well as improvements made at airports. Air transport has very strict rules and regulations as it is the fastest transportation at the international level and requires high costs. In case of an internationally detected infectious diseases and political or financial crises, airline transportation is deeply affected (Bakırc1, 2012: 342). However, despite these risks, it has more advantages over other transportation activities. Due to these advantages, airline transportation is preferred by passengers and accordingly, it constantly develops and progresses.

\section{Transportation of Konya Province}

The diversity and modernization of transportation systems are important factors in the economic and social development of that region. As the transportation system grows and modernizes, commercial life revives, production increases, other sectors are positively affected, social and cultural life is colored, and education and health services improve. It embodies the diversity in the transportation system by road, rail and air in Konya.

\subsection{Konya Province Road Transport}

According to the data of 2018, the Konya province consists of a total 3,158 km of road network, $1,414 \mathrm{~km}$ of it being state roads and $1,744 \mathrm{~km}$ being provincial roads. $1,137.6 \mathrm{~km}$ of these roads are in the form of multi-lane roads, which are considered important in terms of traffic safety. As of 2003, the length of the multi-lane road was 160 kilometers. By constructing $970.6 \mathrm{~km}$ of multi-lane roads, a total of 1,137.6 km of multi-lane road network was reached between 2003 and 2018. The total length of multilane roads increased by 580\% between 2003 and 2018 (Ulaşan ve Erişen Türkiye 2018 Karayolu, 2018: 71). 


\subsection{Konya Province Rail Transport}

Railways are among the preferred transportation systems because they allow large amounts of passenger and freight transportation. The Konya province has a very advantageous location especially in passenger transportation with Konya-Ankara, Konya-Eskişehir and Konya-Istanbul High-Speed Train (HST) services. Considering the length of the railway, the Konya province has a total of $688 \mathrm{~km}$ of railway network, $383 \mathrm{~km}$ of conventional lines and $305 \mathrm{~km}$ of HST lines. In 2018, an average of 3,656,731 passengers traveled from Konya and 1,394,784 tons of freight were transported. Freight transportation is mainly carried out towards Kahramanmaraş, Mersin and Uşak provinces (Ulaşımda ve İletişimde 2003/2019 Konya: 45)

Ankara-Konya High Speed Railway Line was put into operation in 2011 in order to provide access to Çukurova-South East Anatolia from Ankara via Konya. Travel time between Konya and Ankara is 1 hour 45 minutes. An average of 6,000 passengers travel on this line with 20 trips per day (Ulaşan ve Erişen Türkiye 2018 Demiryolu, 2018: 314).

On the other hand, 790 passengers travel on average daily with HSTs, which started to operate between Konya and Eskişehir in 2013. HST passenger trains operated between Konya-Eskişehir in 2013 and started to operate as Konya-Istanbul with the opening of the Eskişehir-Istanbul line in 2014. In addition, the Konya-Pendik line started to operate in 2014 and the Konya-Halkalı line started to operate in 2019. (https://www.tcdd.gov. tr/kurumsal/hakkinda). Travel time between Konya and Istanbul, which is 13 hours by conventional trains, has been reduced to 4 hours and 15 minutes. Since the Konya-Istanbul line was opened, 3 million 441 thousand passengers had traveled until the end of 2018. The occupancy rate between Konya and Istanbul is $86 \%$.

Table 1. Konya Province HST Ridership Data

\begin{tabular}{|l|c|c|c|c|c|c|c|}
\hline HST Route & $\mathbf{2 0 1 1}$ & $\mathbf{2 0 1 2}$ & $\mathbf{2 0 1 3}$ & $\mathbf{2 0 1 4}$ & $\mathbf{2 0 1 5}$ & $\mathbf{2 0 1 6}$ & $\mathbf{2 0 1 7}$ \\
\hline Konya-Ankara & 407 & 1,371 & 1,745 & 1,890 & 1,799 & 1,775 & 2,047 \\
\hline Konya-Eskișehir/İstanbul & & & 198 & 279 & 659 & 684 & 905 \\
\hline
\end{tabular}

Source: TCDD 2017 Annual Report

\subsection{Konya Province Air Transport}

Air transport in Konya is carried out through Konya Airport. Konya airport has a civilmilitary status and was put into service in 2000. Turkish Airlines, Pegasus, Anadolujet, SunEkspress, Corendon and the Freebird airline companies serve as domestic and international lines.

Table 2. Airlines Serving Domestic and International Flights from Konya Airport

\begin{tabular}{|l|l|}
\hline Airline & Destinations \\
\hline Turkish Airlines & İstanbul, Kopenhag \\
\hline Pegasus Airlines & İstanbul-Sabiha Gökçen, Kopenhag, Konya \\
\hline SunExpress & İzmir,Amsterdam,Kopenhag \\
\hline Atlas Global Airlines & İstanbul \\
\hline AnadoluJet & İstanbul-Sabiha Gökçen \\
\hline Corendon Airlines & Airlines operating seasonal charter flights \\
\hline
\end{tabular}




\section{Methodology}

Konya is a province that has a lot of interaction with its external environment due to its geographical location and especially its socio-economic structure. This interaction focuses on education, trade (industry, agriculture, etc.) and tourism. At this point, different types of transportation (road, air and railway) are available to travel within and outside the province, and offer users the opportunity to choose. At this point, determining the relationship between people's demographic characteristics and travel preferences is important for both travel companies and local administrations in terms of transportation strategies and management.

The purpose of this study is to determine the general characteristics of people generally preferring a certain type of transportation during their travels. For this purpose, a survey was conducted and the people were categorized.

Although the population of the study is Konya, taking the population density, geographical distribution of the districts and research constraints into consideration, the study was limited to the participants residing in the central districts of Selcuklu (639.450), Meram (345.813) and Karatay (315.959), which are smaller samples representing Konya. The research was conducted on 1200 participants living in these districts. The survey was applied to 1200 participants who were selected by easy sampling, and who were interviewed face-to-face.

\section{Findings}

In this section, demographic frequency analysis and cluster analysis findings made within the scope of the research are included.

\subsection{Demographic Findings}

Within the scope of the research project, 11 demographic / descriptive questions were asked to the participants. In the cluster analysis made to group the participants according to their travel preferences, 6 variables determined as a result of the consensus were used: the participant's age, occupation, education level, average income of the household, generally preferred transportation type and travel purpose. The demographic distribution of the participants according to these variables is as follows: 
Tablo 3. Demographic features

\begin{tabular}{|c|c|c|c|c|c|c|c|}
\hline \multirow{8}{*}{ 岳 } & & Frequency & percentage & \multirow{8}{*}{ 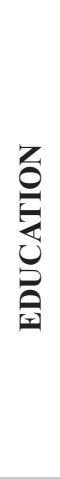 } & & Frequency & percentage \\
\hline & $18-25$ & 751 & 62.8 & & $\begin{array}{c}\text { Primary } \\
\text { school }\end{array}$ & 34 & 2.9 \\
\hline & $26-35$ & 167 & 14 & & $\begin{array}{l}\text { Secondary } \\
\text { school }\end{array}$ & 49 & 4.1 \\
\hline & $36-45$ & 132 & 11 & & High School & 181 & 15.2 \\
\hline & $46-55$ & 83 & 6.9 & & $\begin{array}{l}\text { Associate } \\
\text { degree }\end{array}$ & 167 & 14 \\
\hline & $56-65$ & 50 & 4.2 & & $\begin{array}{l}\text { Bachelor's } \\
\text { degree }\end{array}$ & 704 & 59.2 \\
\hline & 66 and above & 13 & 1.1 & & Postgraduate & 54 & 4.5 \\
\hline & Total & 1196 & 100 & & Total & 1189 & 100 \\
\hline \multirow{12}{*}{ 孞 } & & Frequency & percentage & \multirow{8}{*}{ 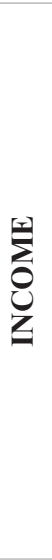 } & & Frequency & percentage \\
\hline & Worker & 51 & 4.3 & & $\begin{array}{l}1500 \mathrm{TL} \text { and } \\
\text { Below }\end{array}$ & 77 & 6.4 \\
\hline & Civil Servant & 89 & 7.5 & & $\begin{array}{c}\text { 1501-3000 } \\
\text { TL }\end{array}$ & 316 & 26.5 \\
\hline & Academician & 19 & 1.6 & & $\begin{array}{l}3001-4500 \\
\text { TL }\end{array}$ & 388 & 32.5 \\
\hline & Housewife & 56 & 4.7 & & $\begin{array}{l}4501-6000 \\
\text { TL }\end{array}$ & 225 & 18.8 \\
\hline & Retired & 41 & 3.4 & & $\begin{array}{l}6001-7500 \\
\text { TL }\end{array}$ & 88 & 7.4 \\
\hline & $\begin{array}{l}\text { Self- } \\
\text { employment }\end{array}$ & 63 & 5.3 & & $\begin{array}{c}7501 \mathrm{TL} \text { and } \\
\text { above }\end{array}$ & 100 & 8.4 \\
\hline & Teacher & 36 & 3 & & Total & 1194 & 100 \\
\hline & $\begin{array}{l}\text { Health } \\
\text { personnel }\end{array}$ & 32 & 2.7 & \multirow{8}{*}{ 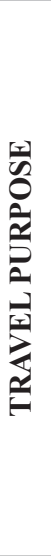 } & & Frequency & percentage \\
\hline & $\begin{array}{l}\text { Private } \\
\text { Sector } \\
\text { Employee }\end{array}$ & 129 & 10.8 & & Visit & 443 & 37 \\
\hline & $\begin{array}{l}\text { Student- } \\
\text { Unemployed } \\
\text { (Other) }\end{array}$ & 675 & 56.7 & & Business & 147 & 12.3 \\
\hline & Total & 1191 & 100 & & $\begin{array}{l}\text { Touristic/ } \\
\text { Vacation }\end{array}$ & 372 & 31.1 \\
\hline \multirow{6}{*}{ 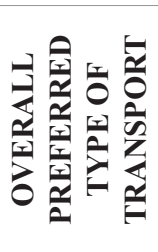 } & & Frequency & percentage & & Education & 199 & 16.6 \\
\hline & Road & 723 & 60.7 & & Health & 15 & 1.3 \\
\hline & Maritime & 8 & 0.7 & & Other & 22 & 1.8 \\
\hline & Air & 275 & 23.1 & & Total & 1198 & 100 \\
\hline & Rail & 185 & 15.5 & & & & \\
\hline & Total & 1191 & 100 & & & & \\
\hline
\end{tabular}

- $62.82 \%$ of the participants are between the ages of $18-25,14 \%$ between the ages of $26-35$ and $11 \%$ between the ages of 36-45. Most of the participants are young people.

- $56.7 \%$ of the participants are students and unemployed, $10.8 \%$ are private sector employees and $7.5 \%$ are civil servants.

- $59.2 \%$ of the participants have a bachelor's degree, $15.2 \%$ of participants graduated from high school and $14 \%$ of them have an associate degree. 
- $32.5 \%$ of the participants have an average monthly household income between 3001-4500 TL, 26.5\% between 1501-3000 TL and 18.8\% between 4501-6000 TL.

- Generally, the preferred type of transportation of the participants was road transport with $60.7 \%$, air transport with $23.1 \%$ and rail transport with $15.5 \%$. Accordingly, the first important transportation type preferred by the participants living in the center of Konya was road and the second most important transportation type was air.

- $37 \%$ of the participants travel for visiting, $31.1 \%$ for touristic / holiday and $16.6 \%$ for education.

\subsection{Cluster Analysis Findings}

Cluster analysis collects the units examined in a study into certain groups according to their similarities. With the classification made, it is aimed to determine the common features of the units and to make the general definition of the clusters formed (Şahin and Hamarat 2002).

Cluster analysis was used to determine the passenger profiles according to their preferred transportation types, in other words, it was used to group the participants according to their demographic characteristics. With the cluster analysis, participants with similar characteristics will be able to come together and the participant profiles will be determined according to the preferred transportation type.

Findings obtained from the answers given to the questionnaire questions in the project to which this study is related were evaluated and a cluster analysis was performed in the context of 6 demographic variables determined by taking expert opinions.

Clustering analysis was performed using the two-stage clustering method, which is frequently used when the number of clusters to be formed is uncertain. The variables used in the analysis are the participant's age, occupation, education level, average household income, generally preferred type of transportation and travel purposes. These 6 variables were analyzed by considering all their categories. The cluster analysis results using the logarithmic probability distance measure (Distance measurement of similarity measures the closeness, that is, the similarity, of the observations for the variables within the clustering variables and is frequently used in the similarity measurement (Kalaycr, 2014:355). The log-likelihood distance can be used when there are continuous and categorical variables in the data (Sel, 2020).) and the BIC (Schwarz's Bayesian Information Criterion) clustering criteria (the method used by the program when determining the number of clusters) are given below. 


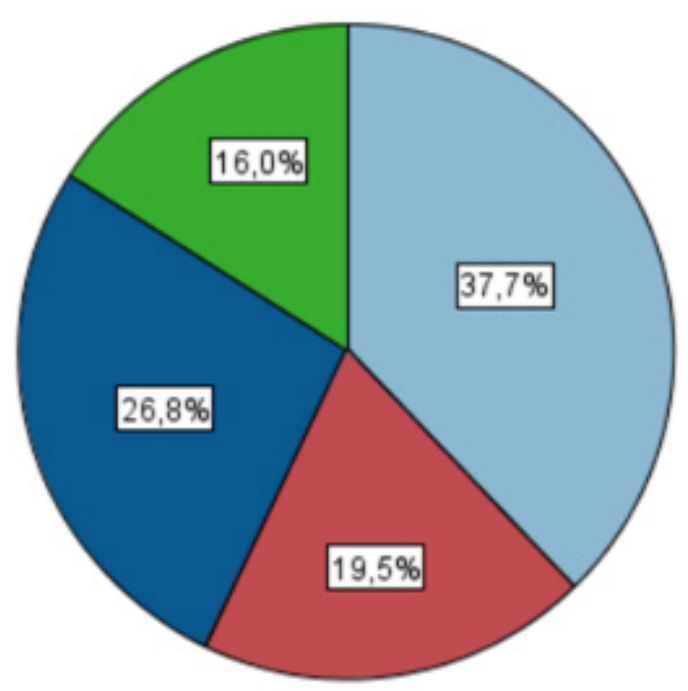

Figure 1. Cluster Sizes

Participants are grouped in 4 clusters according to Figure 1 . The first cluster density was determined as $37.7 \%$, the second cluster density was $19.5 \%$, the third cluster density was $26.8 \%$ and the fourth cluster density was $16 \%$.

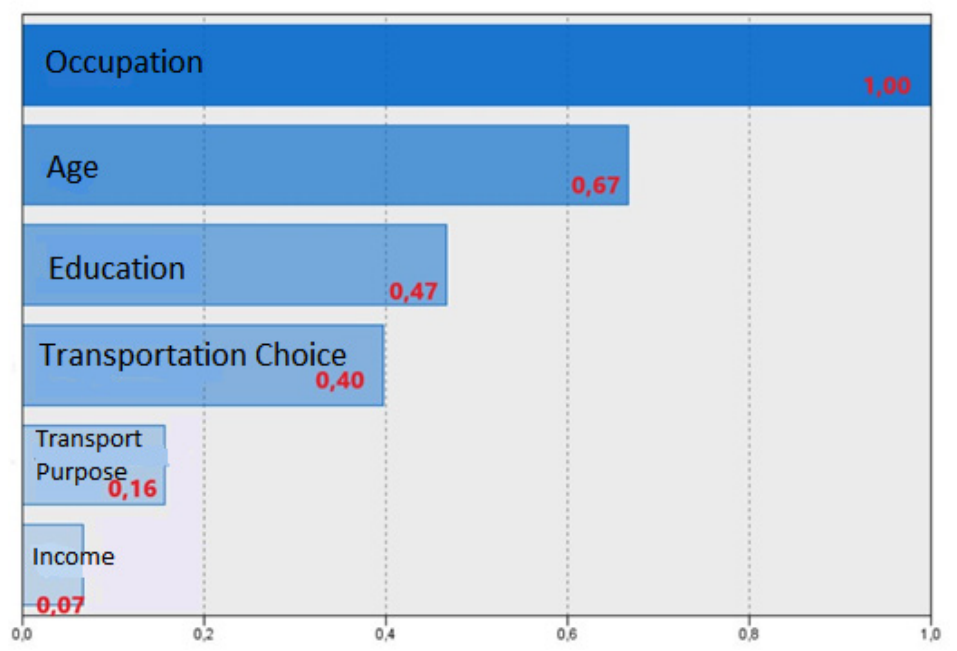

Figure 2. Significance Levels of Variables

According to Figure 2, while the participants were grouped with cluster analysis, the most effective variable was occupation. Then age, education, transportation preference, transportation purpose and income variables were taken into account in the cluster according to their importance level. The transportation type preference variable had a $40 \%$ effect while clustering. 


\section{Clusters}

Input (Predictor) Importance

$\square 1,0 \square 0,8 \square 0,6 \square 0,4 \square 0,2 \square 0,0$

\begin{tabular}{|c|c|c|c|c|}
\hline Cluster & 1 & 3 & 2 & 4 \\
\hline \multicolumn{5}{|l|}{ Label } \\
\hline \multicolumn{5}{|l|}{ Description } \\
\hline Size & $\begin{array}{r}37,7 \% \\
(438)\end{array}$ & $\begin{array}{r}26,8 \% \\
(311)\end{array}$ & $\begin{array}{r}19,5 \% \\
(226)\end{array}$ & $\begin{array}{c}16,0 \% \\
(186)\end{array}$ \\
\hline \multirow[t]{6}{*}{ Inputs } & Other $\stackrel{\$}{ }(95,2 \%)$ & $\begin{array}{l}\text { PrivateStector } \\
\text { Employe } 28,0 \% \text { ) }\end{array}$ & Other $\stackrel{\$ 4}{(92,5 \%)}$ & $\begin{array}{l}\text { Civil } \$ 4 \\
\text { Servant }\end{array}$ \\
\hline & $\frac{\mathrm{S} 2}{18-25 \text { Age }(100,0 \%)}$ & 36- 45 Age $(24,8 \%)$ & $\stackrel{\$ 2}{18-25 \operatorname{Age}(98,2 \%)}$ & $\frac{\mathrm{S} 2}{26-35 \mathrm{Age}(46,8 \%)}$ \\
\hline & $\begin{array}{l}\text { Bachelor'\$5 }(74,9 \%) \\
\text { degree }\end{array}$ & $\begin{array}{l}\text { High } \$ 5 \\
\text { School }^{(35,7 \%)}\end{array}$ & $\begin{array}{l}\text { Bachelor } \$(85,0 \%) \\
\text { degree }\end{array}$ & $\begin{array}{l}\text { Bachelor } \$ 5 \\
\text { degree }\end{array}$ \\
\hline & $\operatorname{Road}^{\mathrm{S8}}(93,8 \%)$ & Road $^{\mathrm{S} 8}(58,8 \%)$ & Air $\quad{ }^{\mathrm{S} 8}(57,1 \%)$ & Road $\$(59,7 \%)$ \\
\hline & $\begin{array}{c}\$ 10 \\
\text { Touristic/Vacation } \\
(35,4 \%)\end{array}$ & $\begin{array}{l}\$ 10 \\
\text { Visit } \quad(46,0 \%)\end{array}$ & $\begin{array}{c}\mathrm{s10} \\
\text { Education }^{(33,2 \%)}\end{array}$ & Visit $\quad \stackrel{S 10}{(41,4 \%)}$ \\
\hline & $\begin{array}{c}\$ 7 \\
3001-4500 \mathrm{TL} \\
(34,5 \%)\end{array}$ & $\begin{array}{c}\$ 7 \\
3001-4500 \mathrm{TL} \\
(34,7 \%)\end{array}$ & $\begin{array}{c}\$ 7 \\
1501-3000 \mathrm{TL} \\
(30,1 \%)\end{array}$ & $\underset{\substack{\$ 3 \\
3001-4500 \mathrm{TL}}}{(31,2 \%)}$ \\
\hline
\end{tabular}

Figure 3. Distribution of Variables in

Among the 4 clusters formed in Figure 3, are the most intense categories in the context of each demographic variable. The general characteristics of the clusters created accordingly are as follows:

Of the participants in the first cluster with a density of $37.7 \%$ (438 participants), $95.2 \%$ are in the student-unemployed occupation group, all of them are between the ages of 18 $25,74.9 \%$ of these participants are bachelor's degree students, $93.8 \%$ of the participants prefer transportation by road, $35.4 \%$ of them travel for touristic purposes and $34.5 \%$ of them have income between 3001-4500 TL.

In the second cluster, whose density is $19.5 \%$ (226 participants), the group with the highest density is the participant group whose transportation preference is the air transport (57.1\%). If we look at the other characteristics of the participants in this cluster, it is seen that they are mostly in the student / unemployed profession group, they are in the age range of 18-25, have a bachelor's degree, they usually travel for education and have an income between 1501-3000 TL. 
Of the participants in the third cluster with a density of $26.8 \%$ (311 participants), $28 \%$ are private sector employees, $24.8 \%$ of them are between $36-45$ years old, $35.7 \%$ of these participants graduated from high school, $58.8 \%$ of them prefer road transportation, $46 \%$ of them travel for visiting purposes and $34.7 \%$ of them are people with an income between 3001-4500 TL.

In the fourth cluster, with a density of $16 \%$ (186 participants), civil servants (37.1\%), 26-35 years olds (46.8\%), participants who have bachelor's degree and students (73.7\%), those who prefer road transport (59.7\%), those traveling for the purpose of visiting (41.4) and those with income between 3001-4500 TL (31.2\%) are mainly grouped together.
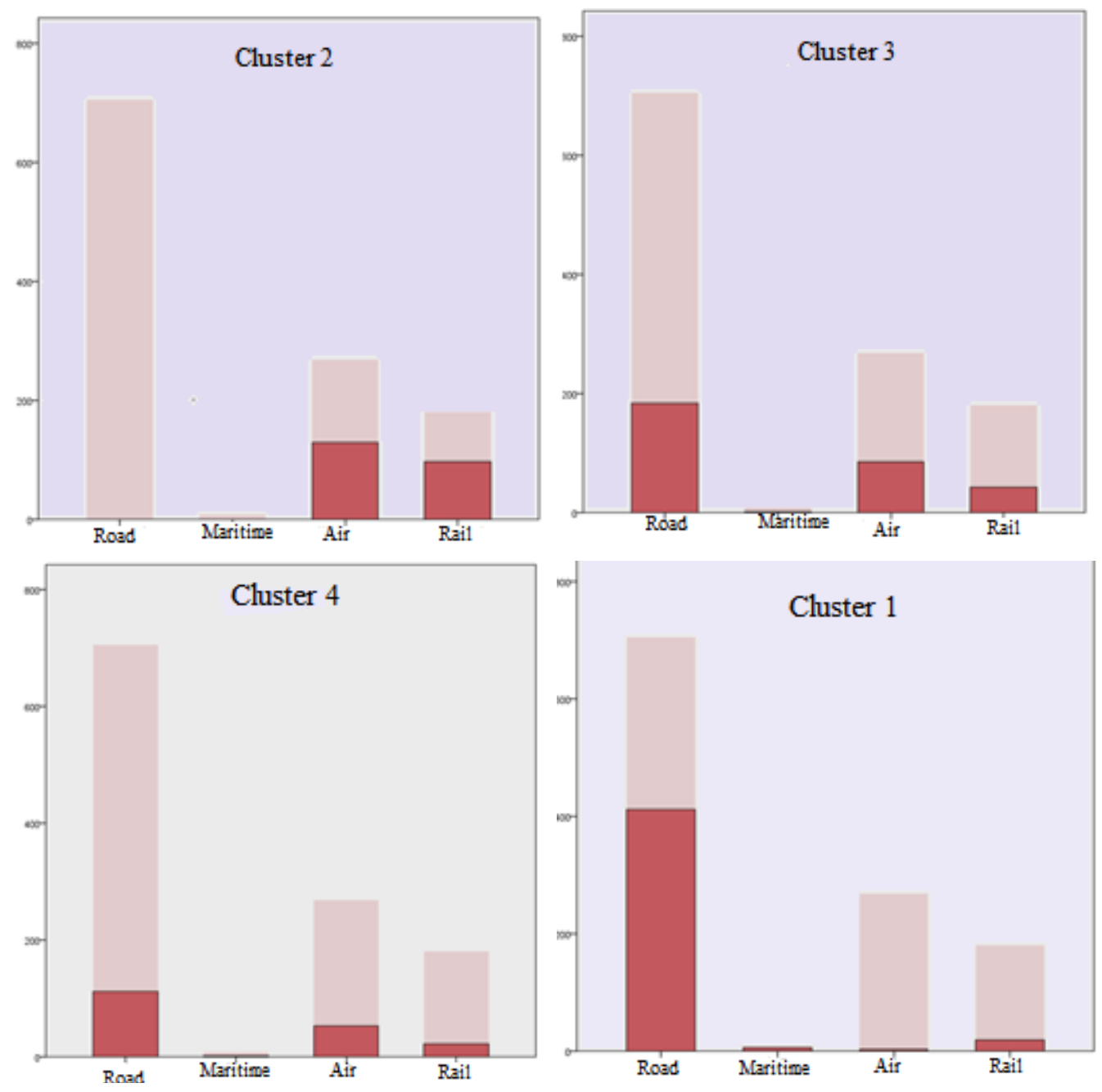

Figure 4. Cluster Densities According to Transportation Preferences

According to Figure 4, it is seen that clusters are formed within the framework of road and air in terms of transportation preferences. Clusters are listed as $2>3>4>1$ according to the density of those who prefer air transportation. The clusters are listed as $1>4>3>$ 2 according to the density of those who prefer road transport. 


\section{Conclusion and Recommendations}

The Konya province is among the largest cities of Turkey in terms of population. A large part of the population is literate and the education level is quite high. Konya is attractive in terms of agriculture and industry sectors (import-export) as well as many cultural and historical riches. In addition, it is one of the rare cities with a diversity potential for tourism such as belief, culture, health, congress, fair, meeting, nature, sports and hunting. It welcomes millions of local and foreign visitors traveling for various purposes. The Konya province hosts many students with its 5 higher education institutions.

All these features of Konya show that it is important to diversify and improve transportation for both arriving and departing passengers. It is expected that transport graph of a city, which is particularly active in tourism, education, agriculture and industry, will increase every year.

For this purpose, the findings obtained from the field research conducted in the Konya province show that the majority of the participants are people whose education level is university. There are 5 universities in Konya and participation of students from outside the province is high at all educational levels (associate degree, undergraduate and graduate) of these universities.

Participants who prefer to travel by road travel mostly for the purpose of visiting, while the participants who prefer to travel by air travel mostly for touristic / holiday purposes and participants who prefer to travel by rail mostly travel for the purpose of visiting.

Konya, due to its geographical location, is in the center of the country and is a city that has the opportunity to reach other provinces by road, rail or air. In addition, all three types of transportation are preferred due to the demographic structure of the province as well as the conditions related to education / health and business (industry).

When the participants are grouped according to some demographic variables, it is seen that the most dominant modes of transportation are road and air. Occupation, age, education, transportation type preference, travel purpose and income variables show the effects on the participants' behavior, respectively. Among these variables, the choice of transportation type is $40 \%$ effective.

Participants were gathered in 4 categories according to the data obtained. Group characteristics of categories created according to these data in terms of the analyzed demographic variables are given in Table 2. 
Table 4. Dense Feastures of Clusters According to Variables

\begin{tabular}{|c|c|c|c|c|}
\hline & Cluster 1 & Cluster 2 & Cluster 3 & Cluster 4 \\
\hline Occupation & $\begin{array}{c}\text { Student / } \\
\text { unemployed }\end{array}$ & $\begin{array}{l}\text { Student / } \\
\text { unemployed }\end{array}$ & $\begin{array}{l}\text { Private Sector } \\
\text { Employee }\end{array}$ & Civil Servant \\
\hline Age & 18-25 Age & 18-25 Age & 36-45 Age & 26-35 Age \\
\hline Education & Bachelor's degree & Bachelor's degree & High School & Bachelor's degree \\
\hline $\begin{array}{l}\text { Transportation } \\
\text { Type }\end{array}$ & Road & Air & Road & Road \\
\hline Travel Purpose & $\begin{array}{l}\text { Touristic / } \\
\text { Vacation }\end{array}$ & Education & Visiting & Visiting \\
\hline Income & $3001-4500 \mathrm{TL}$ & 1501-3000TL & $3001-4500 \mathrm{TL}$ & $3001-4500 \mathrm{TL}$ \\
\hline
\end{tabular}

Considering Table 4, the general characteristics of the group (cluster 2) that prefer air transport in Konya is that they are student / unemployed, are in the age range of 18-25, have a bachelor's degree, travel for educational purposes and have an income of 1501$3000 \mathrm{TL}$. On the other hand, clusters are listed as $2>3>4>1$ according to the density of those who prefer air transportation. The clusters are listed as $1>4>3>2$ according to the density of those who prefer road transport.

According to the results, for the development and improvement of the aviation sector and airline transportation in Konya, companies should make flight plans by taking into account the existing passenger characteristics in cluster 2. Similarly, road transport companies should plan their strategies by taking the existing passenger characteristics in cluster 1 into account. In addition to cluster 1, cluster 3 and 4 are mainly composed of participants who prefer road transport; so companies should also consider the characteristics of these participants. In addition, strategies should be developed especially on marketing in order to encourage potential passengers in other clusters to use any form of transportation.

Informed Consent: Written consent was obtained from the participants.

Peer Review: Externally peer-reviewed.

Author Contributions: Conception/Design of Study- Z.E.I., N.C., A.E.; Data Acquisition- A.E.; Data Analysis/ Interpretation- Z.E.I.; Drafting Manuscript- Z.E.I., N.C., A.E.; Critical Revision of Manuscript- Z.E.I., N.C., A.E.; Final Approval and Accountability- Z.E.I., N.C., A.E.

Conflict of Interest: Authors declared no conflict of interest.

Financial Disclosure: Authors declared no financial support.

Acknowledgement: This study was extracted from the project number 19401020 supported by Selçuk University Scientific Research Projects Coordinatorship.

Bilgilendirilmiş Onam: Katılımcılardan bilgilendirilmiş onam alınmıştır.

Hakem Değerlendirmesi: Dış bağımsız.

Yazar Katkıları: Çalışma Konsepti/Tasarım- Z.E.I., N.C., A.E.; Veri Toplama- A.E.; Veri Analizi/Yorumlama- Z.E.I.; Yazı Taslağ1- Z.E.I., N.C., A.E.; İçeriğin Eleştirel İncelemesi- Z.E.I., N.C., A.E.; Son Onay ve Sorumluluk- Z.E.I., N.C., A.E. Çıkar Çatışması: Yazarlar çıkar çatışması beyan etmemişlerdir. Finansal Destek: Yazarlar finansal destek beyan etmemişlerdir.

Teşekkür: Bu çalışma Selçuk Üniversitesi Bilimsel Araştırma Projeleri Koordinatörlüğü tarafından desteklenen 19401020 numaralı projeden üretilmiştir.

\section{References}

Akgüngör, A.P. ve Demirel, A. (2004). “Türkiye'deki Ulaştırma Sistemlerinin Analizi ve Ulaştırma Politikaları”, Pamukkale Üniversitesi Mühendislik Fakültesi, Mühendislik Bilimleri Dergisi, 10 (3), 423-430. 
Bahar, E. (2018). “Türkiye’de Havayolu İşletmeciliğinin Gelişimi”, Arel Üniversitesi İktisadi İdari Bilimler Fakültesi Ekonomi Yönetim ve Sosyal Araştırmalar Dergisi, 3 (1) İstanbul.

Bakırcı, M. (2012). "Ulaşım Coğrafyası Açısından Türkiye'de Havayolu Ulaşımının Tarihsel Gelişimi ve Mevcut Yapısı”, Marmara Coğrafya Dergisi (25), 340 - 377.

Çekerol, G. S. ve Nalçakan, M. (2011). Lojistik Sektörü İçerisinde Türkiye Demiryolu Yurtiçi Yük Taşıma Talebinin Ridge Regresyonla Analizi, Marmara Üniversitesi İ.İ.B.F. Dergisi. XXXI (II) 321-344.

Deniz, T. (2016), Türkiye'de Ulaşım Sektöründe Yaşanan Değişimler ve Mevcut Durum. Eastern Geographical Review. (36).

Doğan, Z. ve Dikmen Beller, B. (2018). Türkiye'deki Ulaştırma Sektörü ve Ulaştırma Türlerinin Karşılaştırılması, Uluslararası Sosyal Araştırmalar Dergisi, 11(56) 758-770.

Gerede, E. (2002). Havayolu Taşımacılı̆̆ında Küreselleşme ve Havayolu İş birlikleri-THY AO.'da Bir Uygulama. (Yayımlanmamış Doktora Tezi). Anadolu Üniversitesi Sosyal Bilimler Enstitüsü. Eskişehir.

GİSBİR (Türkiye Gemi İnşa Sanayicileri Birliği) (2013). Sektör Raporu: Deniz Taşımacılığı 2010-2013.

https://konya.dhmi.gov.tr/Sayfalar/icerik-detay.aspx?oid=4219 (Date of Acsess:24.10.2019)

https://www.tcdd.gov.tr/kurumsal/hakkinda (Date of Acsess:24.10.2019)

Kalaycı, Ş. (2014). SPSS Uygulamalı Çok Değişkenli İstatistik Teknikleri. 6. Baskı. Asil Yayıncılık. Ankara MEB (Milli Eğitim Bakanlığı) (2011). Ulaştırma Hizmetleri Demir Yolu Taşımacılığı. Ankara.

MEB (Milli Eğitim Bakanlığı) (2011). Ulaştırma Hizmetleri Kara Yolu Taşımacılı̆̆ı. Ankara.

Sel, A. (2020). Veri Madenciliği Kümeleme Yöntemleri Kullanarak Karbon Emisyonu Göstergeleri Açısından Oecd Ülkelerinin Sınıflandırılması. Karadeniz Uluslararası Bilimsel Dergi. Volume: 46, Summer. p. 169-187

Şahin, M. ve Hamarat, B. (2002), G10 - Avrupa Birliği ve OECD Ülkelerinin Sosyo-Ekonomik Benzerliklerinin Fuzzy Kümeleme Analizi İle Belirlenmesi, ODTÜ Uluslarası Ekonomi Kongresi VI, Ankara

T.C Devlet Planlama Teşkilatı (2007). Dokuzuncu Kalkınma Planı 2007-2013 Özel İhtisas Komisyonu Raporu: Denizyolu Ulaşımı. Ankara.

T.C. Gümrük ve Ticaret Bakanlığı Esnaf ve Sanatkârlar Genel Müdürlüğü (2017). Esnaf ve Sanatkârlar Özelinde Sektör analizleri Projesi: Ulaştırma Sektörü. (978-605-5254-26 1) Ankara: T.C. Gümrük ve Ticaret Bakanlığı Yayınları.

TCDD (2020). TCDD Taşımacılık Aş Genel Müdürlüğü 2020 Faaliyet Raporu. Ankara: Strateji Geliştirme Dairesi Başkanlığı TCDD Taşımacılık Aş.

Ulaşan ve Erişen Türkiye 2018 Demiryolu. (2018). https://www.uab.gov.tr/uploads/pages/demiryolu/ demiryolu.pdf (Date of Acsess:24.10.2019)

Ulaşan ve Erişen Türkiye 2018 Karayolu. (2018). https://www.uab.gov.tr/uploads/pages/karayolu/karayolu. pdf (Date of Acsess:24.10.2019)

Ulaşımda ve İletişimde 2003/2019 Konya. https://www.uab.gov.tr/uploads/cities/konya/42-konya.pdf(Date of Acsess: 12.11.2019) 